\title{
Industry 4.0 Market in Poland from the International Perspective
}

\author{
Karolina GRZYB \\ Wroclaw University of Economics, Wroclaw, Poland \\ karolina.grzyb@ue.wroc.pl
}

\begin{abstract}
Digitalization and smart technology application have focused the attention and consolidated the efforts of research schemes, political agendas and business strategies worldwide. The European Union is particularly interested in the deployment of its smart reindustrialization strategy, which is in line with the Industry 4.0 concept, promoted by German government and business entities. The actual impact of the industrial digital transformation is not yet envisaged; however undoubtedly, Poland will be affected by this economic phenomenon. Its competitive advantage on the international market, resulting from low labour costs and central European location, will continue to decrease as digitised, automated and connected industries are less sensitive to cost and geographical limitations. The present study is aimed to assess the level of familiarity with Industry 4.0 concept within Polish industrial sector as well as the potential demand of the domestic market for digital solutions. The paper will also discuss the ability of Polish economy to participate in smart reindustrialisation, which has been deployed and prioritized in the European agenda.
\end{abstract}

Keywords: Industry 4.0, Smart Reindustrialization, Digital Transformation.

\section{$1 \quad$ Introduction}

Digitalization and information technology advancements have taken over the attention of decision makers and entrepreneurs worldwide. Innovation and research activities are focused on creating ever smarter solutions and systems to be broadly applied in our homes, regions and economies. Schumpeter argued that any person seeking profit must innovate; however, the macroeconomic effects of a basic innovation tend to remain unnoticeable. In terms of economic growth, the diffusion of new and disruptive solutions is far more important. It is when the imitators realize that the new product or process could bring significant profits and advantages, and thus begin to invest heavily in them [17]. Yet, transformative innovations are only possible if a critical mass of social actors is ready to commit to them in an early stage, before the outcome seems inevitable [11].

The spread of Industry 4.0, often called the forth industrial revolution, has exemplified the above argument. It was introduced in 2011 at Hannover Messe Industrial Fair and, in a fairly short period, developed from an abstract concept, which denoted industrial digitalization, into a tangible reality with many application projects 
in progress. It became a strategic initiative promoted and financed by the German government within the scope of the High Tech 2020 Strategy with the aim to consolidate the country's technological leadership in mechanical engineering on the global market [6]. The European Union, together with its member states, also recognized the potential of digitizing and developing smart industry as a tool for reindustrializing the European economy. At present, $68 \%$ of EU national governments, including Poland, have put in place domestic policies for the digitization of industry. However, Polish economy is perceived to generate low innovation outputs, underperform in digital skills of employees and lack digital infrastructure, thus its future in the smart economy framework is uncertain [5].

\section{Purpose of the Research}

Industry 4.0 is based on the robotization and automation of production and supply chains using advanced IT programs and the Internet of Things, enabling independent communication between machines and real-time data processing. It is founded on nine technology pillars, which are already applicable on the shop-floor and in business practice. They include: Internet of Things, artificial intelligence, robotics and automated machinery, big data and data analytics, mobile services, 3D printing, cloud technologies, virtual and augmented reality and cybersecurity solutions. In this concept the technology is merely a tool to realize a far more important idea of interoperability and interconnection of products and services, value chains, as well as company's business models. Industry 4.0 is expected to transform production from isolated and independent cells to fully integrated, automated and optimized process flow, leading to great improvements in the overall productivity, efficiency and sustainability of business operations [2]. Its key characteristics include operating in highly flexible, networked and autonomous production environments, early-stage engagement of end users and business partners into the design and value-creation processes, and, as a result, providing extensively personalized and connected products, which share data on consumer satisfaction in real-time. The actual impact of the industrial digital transformation is not yet envisaged; however, it is forecasted that the global market for Industry 4.0 solutions will reach 152.31 billion USD in 2022, whereas it accounted for 66.67 billion USD in 2016 [13]. Germany remained at the forefront of Industry 4.0 integration, which is demonstrated by the market's annual turnover of 5.9 billion EUR in 2017 , an increase by $20 \%$ compared to 2016 [8]. German enterprises declared they would invest approximately $3.3 \%$ of their annual revenue until 2020 in adopting advanced technologies [13].

Poland will be undoubtedly affected by this economic phenomenon. The country's competitive advantage on the international market, resulting from low labour costs and central European location, will continue to decrease as digitised, automated and connected industries are less sensitive to cost and geographical limitations. On the other hand, Poland suffering from the lack of interdisciplinary and digitally skilled workforce as well as innovation and investment capital, is facing the threat of becoming the Industry 4.0 outsider. Therefore, the present study is aimed to assess the level of 
familiarity with Industry 4.0 concept within Polish industrial sector as well as the potential demand of the domestic market for digital solutions. The paper will also discuss the ability of Polish economy to participate in the smart reindustrialisation agenda deployed on the European level.

\section{$3 \quad$ Research Methods and Organization}

Research was conducted by means of diagnostics opinion poll method and survey technique. The study group consisted of thirty-one providers of Industry 4.0 solutions, who operate on the Polish market. They are representatives of companies that offer products and services related to the application of smart industry in business operations and were identified and approached by the author due to their active participation in the Industry 4.0 related events, discussions and media. The study was conducted between April and September 2018.

The majority of respondents (74\%) represented foreign entities operating in Poland, and a significant number of them came from private and large businesses $(45 \%$ and $42 \%$ respectively). Nevertheless, Polish and medium enterprises constituted ca. one third of the research population.

Table 1. Classification of enterprises represented by respondents.

\begin{tabular}{rccc}
\hline \multicolumn{4}{c}{$\begin{array}{c}\text { What type of enterprise do you represent? } \\
\text { (more than 1 answer could be selected) }\end{array}$} \\
\hline $74 \%$ & Foreign & $42 \%$ & Large \\
$32 \%$ & Polish & $26 \%$ & Medium \\
$45 \%$ & Private & $10 \%$ & Small \\
$0 \%$ & Public & $6 \%$ & Micro \\
\hline
\end{tabular}

Foreign enterprises were mostly originated in high-income and developed economies, primarily in Germany, followed by United States, Japan and Switzerland. The majority of respondents operated in automation and robotics industry (see Table 2), and almost a half of them were based in Warsaw. Moreover, $68 \%$ of respondents occupied C-level or middle managerial positions.

Table 2. Industries in which respondents operate.

\begin{tabular}{cccc}
\hline & \multicolumn{3}{c}{$\begin{array}{c}\text { Which industry does your company represent? } \\
\text { (most popular indications) }\end{array}$} \\
\hline $58 \%$ & Automation and robotics & $13 \%$ & IT and analytical software \\
$16 \%$ & Mechanical engineering & $6 \%$ & Electrotechnics \\
\hline
\end{tabular}

The aim of the study was to analyse the Industry 4.0. market in Poland from the supplyside perspective. Other available research to assess the market size and dynamics in Poland, conducted mainly by consulting companies and business entities $[1,14,16]$, 
targeted Industry 4.0 customers, thus enterprises in various industrial sectors. However, in the present study a different approach was adopted and Industry 4.0 suppliers were investigated in order to present their market overview and experience. The questionnaire survey comprised 12 questions and addressed the following problems:

- How familiar are companies in Poland with Industry 4.0?

- What is the structure of the Industry 4.0. market demand?

- Which industries are the end users for Industry 4.0 solutions in Poland?

- What is the demand level for Industry 4.0 in Poland and to what extent has it changed in the recent years?

- Which technologies are offered on the Polish market?

- How does the application of Industry 4.0 solutions affect the customer's business activity?

- Has the implementation cost changed in the recent years?

- Are the Industry 4.0 implementation projects monitored and do they influence the business performance of the customers?

\section{$4 \quad$ Research Outcomes}

The level of Industry 4.0 familiarity among enterprises in Poland was considered low or moderate. Study participants suggested that even though the domestic companies had heard of the concept, they did not know what it meant (52\%) or they understood its basic assumptions (48\%) (see Fig. 1).

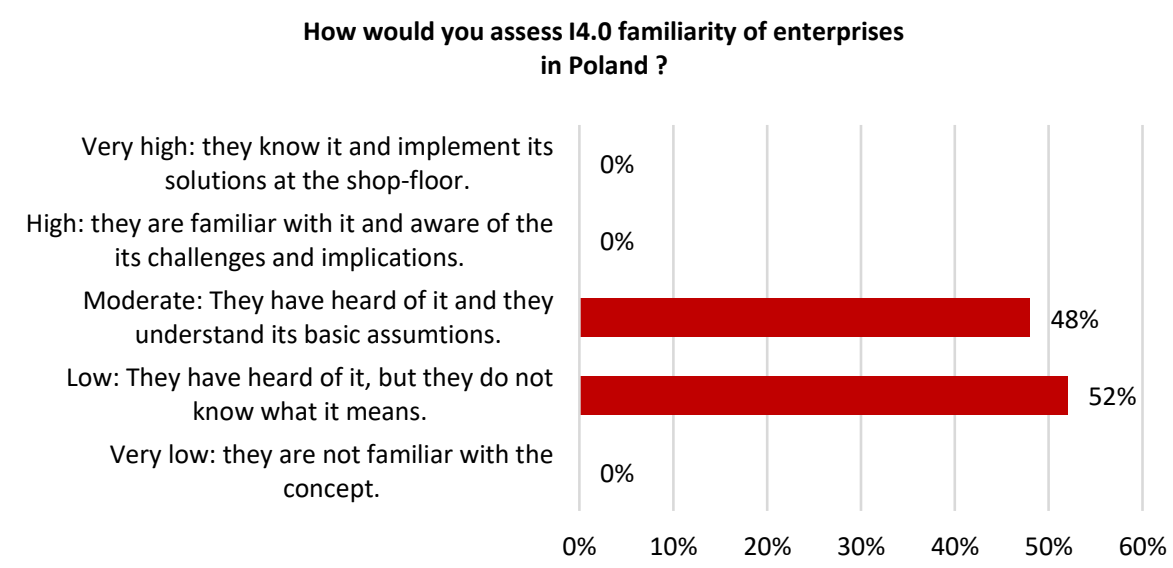

Fig. 1. Perceived level of Industry 4.0 familiarity of enterprises in Poland.

Foreign and large enterprises prevailed not only among respondents, but also on the demand side of the market. They were believed to be fully familiar with Industry 4.0 and generate the highest demand on the Polish market (respectively: $97 \%$ and $94 \%$ of foreign entities, and $90 \%$ and $81 \%$ of large enterprises - see Fig. 2). 


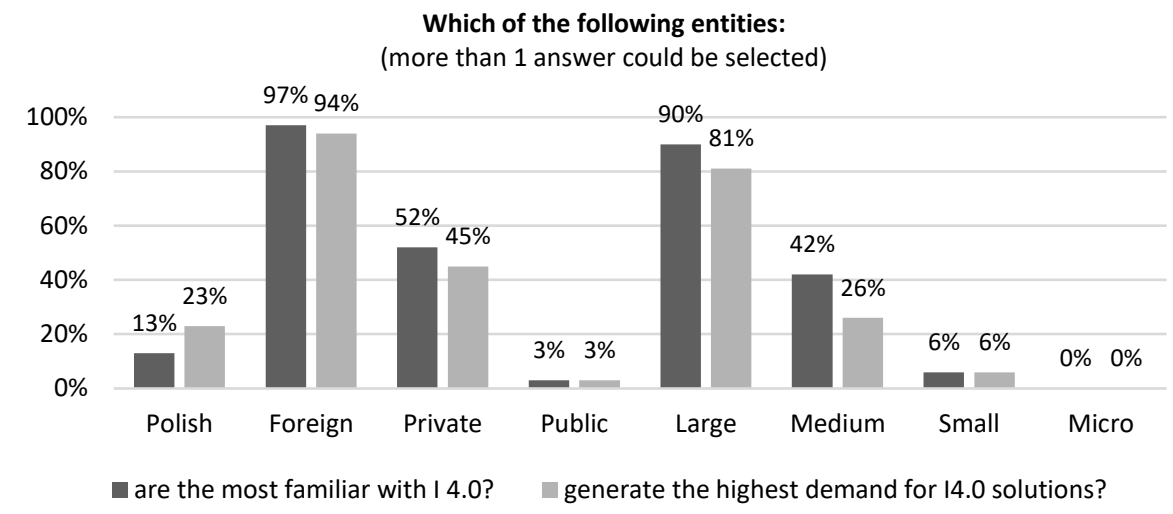

Fig. 2. Familiarity with Industry 4.0 and market demand in Poland.

Only $13 \%$ of respondents admitted that Polish companies were fully aware of the industrial revolution, and $23 \%$ saw them generate the highest demand for digital technologies. Medium enterprises were perceived somewhat better, especially in terms of Industry 4.0 familiarity (42\%). The overall level of demand for smart solutions in Poland was identified as low, which means that manufacturing companies are interested in Industry 4.0 technologies, but they are facing significant demand barriers. Nonetheless, almost $40 \%$ of study participants noticed prospects for market growth or stated that enterprises actually began to adopt Industry 4.0 in Poland. Moreover, as many as $87 \%$ declared that the demand for smart products and services slightly or significantly increased in the past three years, whereas the implementation cost remained more or less constant (see Fig. 3).

In the past three years in Poland, to what extent:

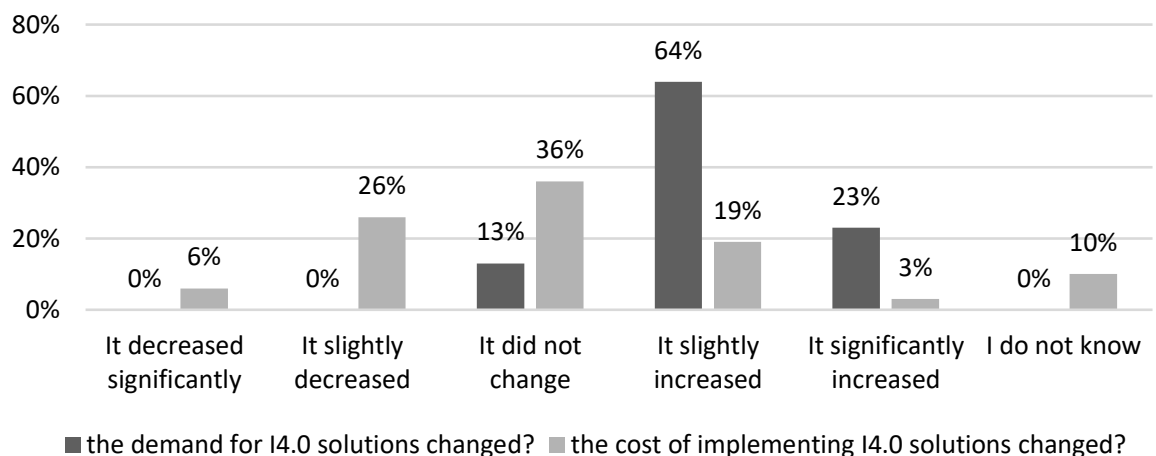

Fig. 3. Perceived change in the demand and implementation cost for Industry 4.0 solutions in Poland.

The highest demand for Industry 4.0 technologies was observed in automotive sector $(93 \%)$, followed by mechanical engineering (45\%), pharmaceutical $(35 \%)$, aerospace 
(33\%), food processing (26\%) and white goods (19\%) industries, which significantly contribute to the Polish economy, but their market leaders are usually multinational and large enterprises. Thus, an interesting outcome was revealed with regards to the adoption of smart solutions by small and medium enterprises (SMEs). Despite the fact that $52 \%$ of study participants considered Polish SMEs to be incapable of implementing Industry 4.0 in the near future, as many as $42 \%$ believed that they would not only participate in the industrial revolution, but also improve their competitive position with this regard. Interestingly enough, $32 \%$ of respondents believed that whether or not Polish SMEs applied smart industrial solutions, it would have no effect on their market position. Such inconsistency in the assessment of Industry 4.0 impact on SMEs might result from the fact that they are lagging behind large companies in digital transformation; however, they are crucial to the supplier network, thus the gap must not be increased [18].

Among smart technologies offered to the market, process automation was mostly indicated. Other prevailing Industry 4.0 solutions were: Internet of Things, predictive maintenance, robotics, cloud computing, operating and information systems integration, and RFID communication (see Table 3).

Table 3. Industry 4.0 solutions offered by respondents to the Polish market.

\begin{tabular}{cccc}
\hline & $\begin{array}{c}\text { Which of the following I4.0 solutions does your company offer? } \\
\text { (more than 1 answer could be selected, most popular indications) }\end{array}$ \\
\hline $74 \%$ & Process automation & $42 \%$ & RFID \\
$55 \%$ & Internet of Things & $35 \%$ & Sensors \\
$52 \%$ & Predictive maintenance & $35 \%$ & Big data analytics \\
$48 \%$ & Robotics & $32 \%$ & Cybersecurity solutions \\
$45 \%$ & Cloud computing & $32 \%$ & Virtual and augmented reality \\
$45 \%$ & OT and IT integration & $16 \%$ & Additive manufacturing \\
\hline
\end{tabular}

Respondents were strongly convinced that smart technologies would make their customers achieve: higher efficiency (93\%), cost reduction (90\%), improved competitive position (77\%), less equipment failures (68\%), improved work safety $(64 \%)$ and higher consumer satisfaction (48\%). This is particularly interesting as $61 \%$ also declared to collect information from customers regarding the actual impact of Industry 4.0 projects deployed in their business activities. Moreover, 55\% stated that such projects were part of the company's long-term development strategy, whereas one third admitted to implement projects not related to any internal strategy. At the same time, the nature of almost a half of Industry 4.0 completed projects depended on the business relationship between the customer and the supplier (see Fig. 4). 


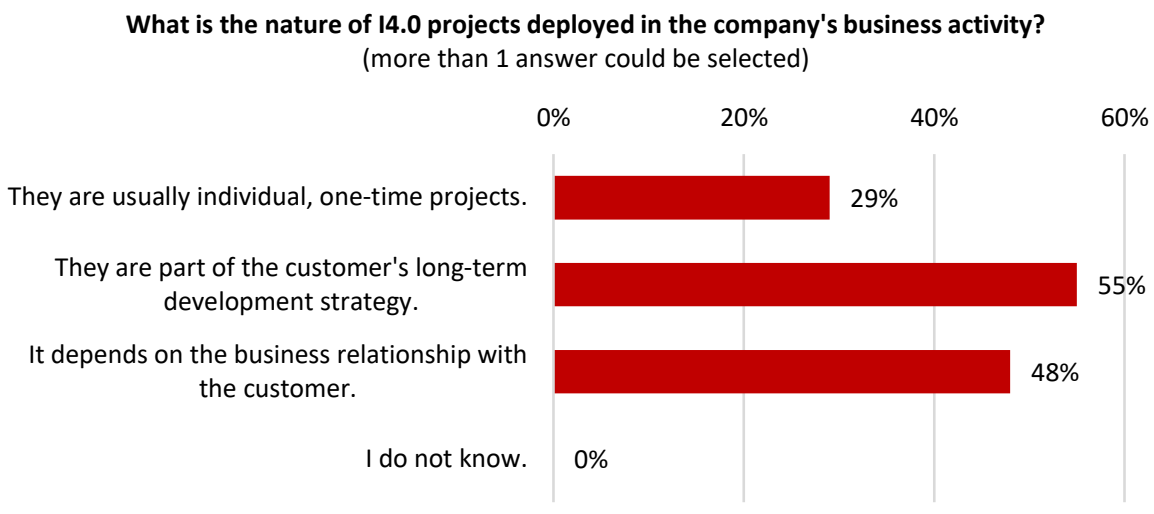

Fig. 4. Business character of Industry 4.0 projects deployed on the Polish market.

\section{Discussion}

Roland Berger, a German consulting company, performed analysis on the progress of national economies in Europe towards smart reindustrialisation. Their Industry 4.0 Readiness Index comprises two categories: "industrial excellence" (based on: production process sophistication, degree of automation, workforce readiness, innovation intensity) and "value network" (estimated upon: high value added, industry openness, innovation network, internet sophistication) and divides countries into four groups presented in Table 4:

Table 4. Industry 4.0 Readiness Index 2016 [15].

\begin{tabular}{lll}
\hline Group name & Characteristics & Countries \\
\hline Frontrunners & $\begin{array}{l}\text { Large industrial base, modernised, } \\
\text { development-oriented business } \\
\text { conditions and technologies; }\end{array}$ & $\begin{array}{l}\text { Germany, Ireland, Finland, } \\
\text { Sweden, Austria }\end{array}$ \\
Potentialists & $\begin{array}{l}\text { Manufacturing industry in decline, } \\
\text { possess capital and resources to } \\
\text { implement Industry 4.0 solutions; }\end{array}$ & $\begin{array}{l}\text { Belgium, Denmark, } \\
\text { Netherlands, UK, France }\end{array}$ \\
Traditionalists & $\begin{array}{l}\text { Thriving, sound industrial base, but } \\
\text { traditional, not ready for digitalisation; }\end{array}$ & $\begin{array}{l}\text { Czech Republic, Slovakia, } \\
\text { Slovenia, Hungary, Lithuania }\end{array}$ \\
Hesitators & $\begin{array}{l}\text { Lack of reliable industrial base, tend to } \\
\text { suffer from fiscal problems, not able to } \\
\text { transform their economy to digital; }\end{array}$ & $\begin{array}{l}\text { Italy, Spain, Portugal, } \\
\text { Poland, Estonia, Croatia, } \\
\text { Bulgaria }\end{array}$ \\
\hline
\end{tabular}

Poland was classified as an economy resistant to industrial transformation, whereas its neighbouring countries in Central and Eastern Europe were ranked higher due to a better perception of their national manufacturing sectors and governance systems. 
According to the Digital Transformation Scoreboard, used by the European Commission, as a monitoring tool for the Digitising European Industry (DEI) strategy adopted in 2016, the area of digitalization in Polish industrial sectors needs to be fully addressed as the country performs significantly below the EU-average [5]. Additionally, Poland has been repeatedly ranked the second worst country in terms of digital technology integration, a composite of the European Union's Digital Economy and Society Index (DESI), which measures the member states' progress in adopting smart solutions. Its distance to the ranking leaders: Denmark, Finland and Ireland, has increased as well [4].

Certainly, applying smart technologies is a challenge not only in emerging economies. According to IDC European Vertical Market Surveys, as many as $44 \%$ of German enterprises are qualified as "digital beginners" due to having integrated only four out of nine technological solutions, whereas $21 \%$ are perceived as "making digital progress". Fully digital organizations constitute less than $2 \%$ of the German business population, but the share is significantly higher among large enterprises (16\%) [9]. In the European economy, the implementation of digital technologies strongly depends on the company size. SMEs significantly lag behind large enterprises in adopting data sharing IT infrastructure that include: ERP, cloud, CRM, RFID, supply chain management and social media [3].

The study on smart industry in Poland, conducted in 2016 by Siemens, proved that only one fourth of Polish managers in medium and large enterprises were familiar with the concept, yet many companies had already applied advanced manufacturing technologies in some areas of their business practice. Those were: process automation and robotics, big data and data mining, Internet of Things, cloud computing RFID and MEMS (sensors). Even though, large and multinational companies operating in Poland were more successful in the adoption of digital solutions than medium and Polish enterprises, an overall positive attitude towards the technological advancement of the Polish industrial sector was visible [16].

PwC outlined a similar finding in their report on challenges and opportunities that result from the industrial revolution. Polish respondents were particularly positive in the assessment of their digital progress so far (see Table 5).

Table 5. Companies that declare high level of digitalisation of their business activities [14].

\begin{tabular}{lcc}
\hline Area of digitalisation & Poland & World \\
\hline Vertical value chain & $52 \%$ & $41 \%$ \\
Horizontal value chain & $46 \%$ & $34 \%$ \\
$\begin{array}{l}\text { Digital business models } \\
\begin{array}{l}\text { Development of products } \\
\text { and technique }\end{array}\end{array}$ & $36 \%$ & $29 \%$ \\
$\begin{array}{l}\text { Customer approach, } \\
\text { distribution and marketing } \\
\text { channels }\end{array}$ & $53 \%$ & $42 \%$ \\
\hline
\end{tabular}


In each of the indicated areas, Polish results were more optimistic than the world average. However, according to $\mathrm{PwC}$, a large share of domestic companies continued to invest in automating individual cells on the shop-floor rather than creating cyberphysical systems within the Industry 4.0 framework. Thus, due to the historically poor condition of Polish industrial sector, respondents mistakenly perceived their recent development as manifestation of the smart revolution. The main barriers identified with regards to digital investments in Poland were high implementation costs, lack of digital strategy, as well as insufficient infrastructure, i.e. poor broadband coverage. However, study participants declared they would invest $7.7 \%$ of the company annual revenue until 2020 on digital solutions and expected a full return on investment within a two-year period [14].

Despite the optimistic approach of enterprises in Poland, Eurostat data on digital economy and society with regards to e-business leave no delusions to the fact that Polish companies lag behind the EU average and leading economies (see Table 6).

Table 6. E-business in Poland and the European Union in 2017 [7].

\begin{tabular}{lccc}
\hline Percent of enterprises which adopted: & Poland & EU average & EU leader \\
\hline $\begin{array}{l}\text { ERP software to share information between } \\
\text { different functional areas }\end{array}$ & $26 \%$ & $34 \%$ & $54 \%$ \\
$\begin{array}{l}\text { CRM software to capture, store and make available } \\
\text { client information to other business functions }\end{array}$ & $23 \%$ & $32 \%$ & $46 \%$ \\
$\begin{array}{l}\text { RFID for aftersales product identification as part of } \\
\text { the production and service delivery }\end{array}$ & $3 \%$ & $4 \%$ & $16 \%$ \\
$\begin{array}{l}\text { Processes automatically linked to those of their } \\
\text { suppliers and/or customers }\end{array}$ & $21 \%$ & $18 \%$ & $30 \%$ \\
$\begin{array}{l}\text { Cloud computing services purchased on the Internet } \\
\text { Big data analytics from any data source }\end{array}$ & $10 \%$ & nd. & $51 \%$ \\
\hline
\end{tabular}

In terms of e-business, Poland is outperforming only in supply chain management by means of the automation of processes to integrate with customers and suppliers. In all other aspects, related to integration of internal processes, cloud computing services and big data analytics, domestic enterprises remain below the EU average and perform significantly lower than the leading member states. Similarly, in terms of robot population density, the world's average in 2016, estimated at 74 units per 10k inhabitants, doubled the robotization level in Poland (32 units), while in Germany it accounted for 309 units [12]. 


\section{Conclusions}

The industrial digital transformation will determine the position of the Polish economy in the worldwide production networks and value chains. Despite the fact that domestic companies present a certain level of optimism with regards to their technological advancement and capacity, European statistical data and indicators suggest that Polish economy is lagging behind other member states in terms of digital performance. Reports published on Industry 4.0 and its market perspectives were focused on a selfassessment of medium and large enterprises which presented an extremely positive approach to business digital transformation and declared high level of advancement in integrating smart technologies. Nevertheless, research outcomes, described in the present article, confirmed that Polish companies are not fully familiar with the Industry 4.0 concept, even though they begin to invest in its adoption.

Industry 4.0 market in Poland is immature and its development is dominated and driven by multinational and large enterprises in the following industrial sectors: automotive, mechanical engineering, pharmaceutical, aerospace, food processing and white goods. Foreign entities also prevail on the supply side and they operate mainly in the field of process automation and robotics; however, they offer a full scope of Industry 4.0 products and services to the Polish customers. Despite the fact that industrial SMEs are perceived to lack the capability to adopt digital transformation in the near future, it is also believed that it would leverage their competitive market position. The demand for Industry 4.0 in Poland is growing, although companies face investment barriers. Moreover, the implementation cost, which has not changed significantly in the recent years, could become an enabler for small and medium manufacturing companies to invest in digital transformation.

Industry 4.0 is believed to bring significant benefits in the field of: efficiency improvement, cost reduction, competitive position, failure predictivity, work safety and consumer satisfaction. Importantly enough, the majority of projects implemented within smart industry framework were due to the company's log-term development strategy. Moreover, in accordance to Industry 4.0 principles, the majority of projects do not end up solely with technology integration, but they continue to provide data to the supply side on their actual impact on the company's business performance.

\section{References}

1. Astor: Przemysł 4.0 rewolucja już tu jest. Co o niej wiesz?, goo.gl/Bh7Th3, last accessed 2018/10/27.

2. Boston Consulting Group: Industry 4.0: The Future of Productivity and Growth in Manufacturing Industries, goo.gl/X5Ayns, last accessed 2018/10/27.

3. European Commission: DESI Report 2018 - Integration of Digital Technology, https://goo.gl/t7E1wj, last accessed 2018/10/27.

4. European Commission: Digital Economy and Society Index, https://digital-agendadata.eu/datasets/desi/visualizations, last accessed 2018/10/27.

5. European Commission: EU businesses go digital: Opportunities, outcomes and uptake. Digital Transformation Scoreboard, . https://ec.europa.eu/growth/tools- 
databases/dem/monitor/sites/default/files/Digital\%20Transformation\%20Scoreboard\%202 018_0.pdf, last accessed 2018/10/27.

6. European Commission: Germany: Industry 4.0. Digital Transformation Monitor, https://goo.gl/SYiuYv, last accessed 2018/10/27.

7. Eurostat, https://ec.europa.eu/eurostat/data/database, last accessed 2018/10/27.

8. Germany Trade \& Invest: Industrie 4.0 Germany Market Report and Outlook, https://goo.gl/Zhnt8X, last accessed 2018/10/27.

9. Götz, M., Gracel, J.: The Fourth-Generation Industry (Industry 4.0) - challenges to research in the international context. Vistula Scientific Quarterly 1(51), 217-235 (2017).

10. Industry 4.0 Market worth 152.31 Billion USD by 2022, https://www.marketsandmarkets.com/PressReleases/industry-4.asp, last accessed: 2018/11/24.

11. Muscio, A., Ciffolilli, A.: Industry 4.0: national and regional comparative advantages in key enabling technologies. European Planning Studies 26(12), 2323-2343 (2018). DOI: 10.1080/09654313.2018.1529145.

12. Robot density rises globally - International Federation of Robotics, https://ifr.org/ifr-pressreleases/news/robot-density-rises-globally, last accessed 2018/10/27.

13. PwC: Industry 4.0: Opportunities and challenges of the industrial internet, https://www.pwc.nl/en/assets/documents/pwc-industrie-4-0.pdf, last accessed: 2018/09/09.

14. PwC: Przemysł 4.0, czyli wyzwania współczesnej produkcji, https://www.pwc.pl/pl/pdf/przemysl-4-0-raport.pdf, last accessed 2018/10/27.

15. Roland Berger: Think Act: Industry 4.0 The new industrial revolution How Europe will succeed, http://www.iberglobal.com/files/Roland_Berger_Industry.pdf, last accessed: 2018/10/27.

16. Siemens: Smart Industry Polska 2016, https://publikacje.siemensinfo.com/pdf/123/Raport\%20Smart\%20Industry\%20Polska\%202016.pdf, last accessed: 2018/10/27.

17. Śledzik, K.: Schumpeter's view on innovation and entrepreneurship. Management Trends in Theory and Practice 1(51), 89-95 (2013). DOI: 10.2139/ssrn.2257783.

18. Sommer, L.: Industrial revolution - industry 4.0: Are German manufacturing SMEs the first victims of this revolution?. Journal of Industrial Engineering and Management 8(5), 15121532 (2015). DOI: 10.3926/jiem.1470. 